\title{
Host-parasite relationships of Zootoca vivipara (Sauria: Lacertidae) in the Pyrenees (North Spain)
}

\author{
Vanessa Sanchis ${ }^{1}$, Juan M. Roig ${ }^{2}$, Miguel A. Carretero ${ }^{2}$, Vicente Roca $^{1}$ and Gustavo A. Llorente ${ }^{2}$ \\ ${ }^{1}$ Departament de Biologia Animal, Facultat de Biologia, Universitat de València, C/ Dr. Moliner, 50, 46100 Burjassot, València, \\ Spain; \\ ${ }^{2}$ Departament de Biologia Animal (Vertebrats), Facultat de Biologia, Universitat de Barcelona, Avgda. Diagonal, 645, 08028 \\ Barcelona, Spain
}

Key words: helminths, Oswaldocruzia filiformis, host-parasite relationships, Zootoca vivipara, Pyrenees, Spain

\begin{abstract}
The helminths infesting the common lizard, Zootoca vivipara (Jacquin, 1787), were studied with special attention to the relations between the number of nematodes, Oswaldocruzia filiformis (Goeze,1782), and the size, sex and age class of the host. The possible seasonality of the parasite intensity and the relationship with the feeding habits of the host were also tested. Helminth infracommunities of Z. vivipara were depauperate with lizards harbouring only two species, the trematode Plagiorchis molini (Lent et Freitas, 1940) and the nematode O. filiformis. A positive correlation between host size and the number of $O$. filiformis was found for female Z. vivipara. However, no correlation was detected between intensity and sex or age class. The feeding habits of $Z$. vivipara, the isolation of the population studied and the low level of interaction with other reptilian or amphibian species are suggested as the causes of the depauperate helminth infracommunities found in this lacertid lizard.
\end{abstract}

Zootoca vivipara (Jacquin, 1787) is a small grounddwelling lacertid lizard that ranges in Eurasia from northern Spain to Japan (Böhme 1997). It is one of the few lizards that exhibit reproductive bimodality (Lantz 1927). The only populations laying eggs are found in northern Spain (Braña and Bea 1987) and in French Aquitaine (Heulin et al. 1994), whereas all others are viviparous. One of these oviparous populations, the diet and reproduction of which have previously been analysed (Carretero et al. 1996, Roig et al. 1996, Roig 1998), is the subject of this parasitological study. Little is known about the helminth fauna of this lacertid, and even less about host-parasite relationships. Thirteen species of parasites were identified in the former USSR (Sharpilo 1976) and seven species were recorded in Poland (Lewin 1992a). In Spain, only one parasite species has been recorded (García-Adell and Roca 1988) from a small number of hosts. In this study we analyse the prevalence, intensity and helminth diversity of parasites of common lizard in an alpine meadow habitat, specifically addressing the following questions: (i) What is the helminth fauna of $Z$. vivipara in the Central Pyrenees? (ii) What are the prevalence and intensity of infection of helminths found in the host? (iii) Is there a relationship between the number of specimens of the main helminth species [the nematode Oswaldocruzia filiformis (Goeze, 1782)] with lizard size? (iv) Is there a relationship between the helminth intensity ( $O$. filiformis) and the sex and size of the host? $(v)$ Does the prevalence of parasites $(O$. filiformis) vary seasonally? (vi) What is the relationship between the feeding habits of the host and infection?

\section{MATERIALS AND METHODS}

The study area was an alpine meadow located at $1800 \mathrm{~m}$ of altitude, in the Central Pyrenees (Pla de Beret, Salardú, Naut Aran, U.T.M. grid $\left.31 \mathrm{~T} \mathrm{CH3434;} 1^{\circ} 01^{\prime} \mathrm{E}, 42^{\circ} 44^{\prime} \mathrm{N}\right)$, dominated by heather (Calluna vulgaris) and, to a lesser degree, common juniper (Juniperus communis). The annual mean temperature is $9.7^{\circ} \mathrm{C}$ and annual total precipitation $918.9 \mathrm{~mm}$ (30 years mean, Panareda and Nuet 1973). Z. vivipara was the only lacertid species found at this site although some specimens of Podarcis muralis (Laurenti, 1768) were observed in adjacent areas.

From April to October 1995, 129 lizards were collected in a systematic field sampling carried out 15 days apart. An additional sample of eight pregnant females was captured in the first half of July 1997. Lizards with developed gonads during the reproductive period were considered adults and the minimum sizes of these reproductive lizards were determined for each sex. Outside the reproductive period, only those lizards with body size larger than these minima were included in the adult class (Carretero and Llorente 1997).

All lizards captured were killed with chloroform and frozen. Once in the laboratory, they were dissected and their digestive tract, heart, lungs, and liver were removed and opened in Ringer's solution for microscopical examination. Helminths were counted, washed in distilled water, fixed, mounted using standard techniques, and identified to species.

The use of descriptive ecological terms follows Bush et al. (1997). Brillouin's index of diversity (Magurran 1988) was calculated for each helminth infracommunity.

For each lizard, the snout-vent-length (SVL), together with a number of parameters associated with reproduction (gonad weight, epididymis and oviduct width) and body condition (fat bodies and liver weight, tail base section) were measured in 
both sexes (see Carretero et al. 1996, Roig et al. 1996). Callipers $(0.01 \mathrm{~mm}$ precision $)$ were used for linear measurement and weights were recorded with a digital balance (0.0001 g precision). Regression residuals between all variables and SVL (both log-transformed) were calculated to standardise variables to animal size (see Carretero et al. 1996, Roig et al. 1996).

Since the intensity of infection (number of helminths per host) was not normally distributed, non-parametric statistics were used when appropriate. For certain analyses, mean size of each helminth sex was calculated for each infected host in order to avoid pseudoreplication.

Log-linear models (Bizquerra 1989, Jobson 1992) were used for analysing simultaneously several categorical variables, including the effects of different host factors (size, sex, season) and the presence of helminths. An automatic procedure was performed (Anonymous 1999). First, a model with no relationships between factors was fitted; if that model did not fit, then a model with all two-way interactions was fitted. If this also failed to fit, then all three-way interactions were fitted, and so on. Finally, non-significant interactions were eliminated. The resulting model included the minimum number of interactions necessary to fit the observed table. The statistical significance was assessed by maximum likelihood and Pearson $\chi^{2}$ tests (Bizquerra 1989).

\section{RESULTS}

The overall prevalence of infection of the Zootoca vivipara population in the Central Pyrenees was $39.42 \%$. The prevalence was $37.9 \%$ for Oswaldocruzia filiformis and $2.2 \%$ for Plagiorchis molini. No seasonal patterns of occurrence were noted for $O$. filiformis (Fig. 1). No significant correlation was found between the prevalences of $O$. filiformis and monthly rainfall $[\mathrm{R}=0.12, \mathrm{~F}(1,5)=0.07, \mathrm{p}<0.78, \mathrm{n} . \mathrm{s}$.$] .$

The helminth community was only composed of two helminth species (Table 1). The digenean P. molini was found in only three large lizards ( 2 adult males and 1 adult female collected in August and July). The mean value of Brillouin's index of diversity was 0.0025 $(\mathrm{SD}=0.029$, range $=0-0.346)$. Only the nematode $O$. filiformis was abundant enough to be studied in detail. Considering only $O$. filiformis, individual lacertid lizards harboured a mean of 2.4 individual helminths $(\mathrm{SD}=2.00$, range $=1-10)$.

A significant correlation between host size and the number of $O$. filiformis was found for female $Z$. vivipara $\left(\mathrm{R}_{\text {Spearman }}=0.38, \mathrm{n}=61, \mathrm{p}=0.002\right.$; see Fig. 2$)$ but not for males $\left(\mathrm{R}_{\text {Spearman }}=0.17, \mathrm{n}=76, \mathrm{p}=0.13\right)$. A sexual dimorphism in size was detected in adult lizards, with females being larger than males (mean SVL \pm standard error in $\mathrm{mm}$ : females $50.94 \pm 0.49$, males $48.25 \pm 0.39 ; \mathrm{T}=4.13,83$ d.f., $\mathrm{p}=0.00008$ ).

After restricting the study to the adult lizards, the intensity of infection by $O$. filiformis was found to be unrelated to gonad development and the body condition of the host $\left(\mathrm{R}_{\text {Spearman }}\right)$. Furthermore, in female lizards infection was not affected by pregnancy. An apparent

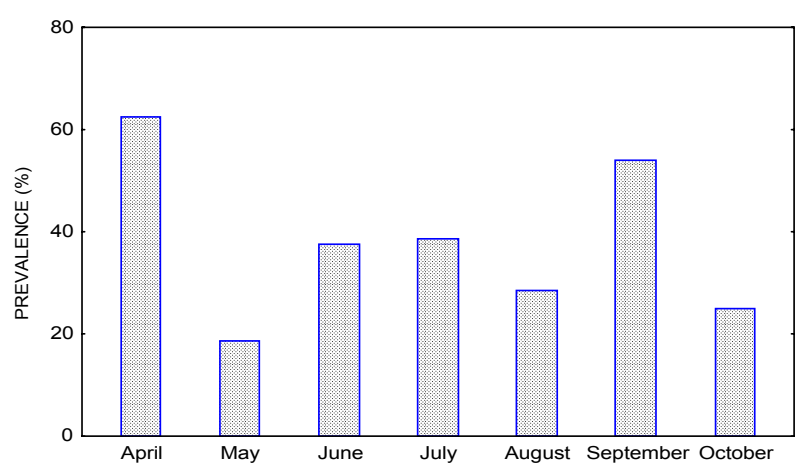

Fig. 1. Monthly prevalence of Oswaldocruzia filiformis in Zootoca vivipara (1995).

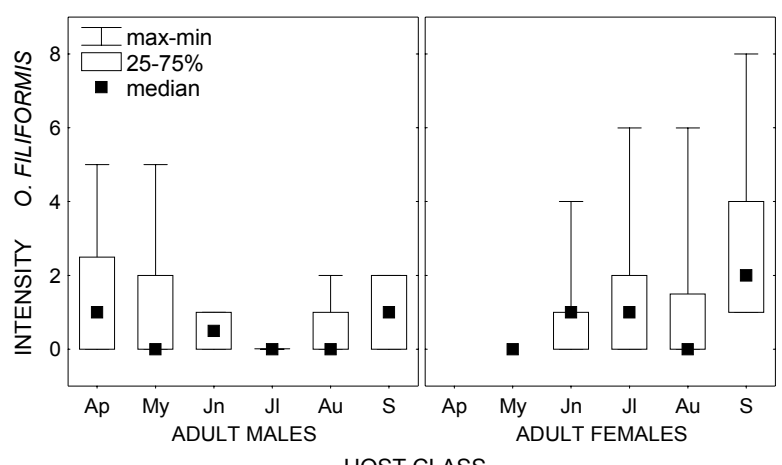

Fig. 2. Number of helminths (Oswaldocruzia filiformis) found throughout the year in adult Zootoca vivipara, according to the sex of the host.

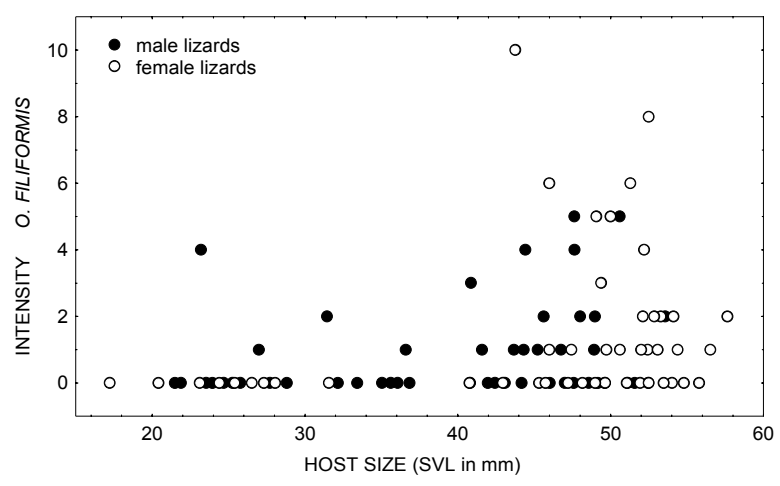

Fig. 3. Variation in the intensity of Oswaldocruzia filiformis with size and sex of the host, Zootoca vivipara.

annual variation in the number of parasites was observed (Fig. 3). For instance, all seven adult females collected in September were infected. However, no statistical differences were found in either males or females (Kruskal-Wallis tests). 
Table 1. Prevalence and intensity of the helminths infecting Zootoca vivipara, according to host sex, age class, and month of sampling.

\begin{tabular}{|c|c|c|c|c|c|c|}
\hline \multirow[b]{2}{*}{ Helminth species } & \multirow[b]{2}{*}{ Host class } & \multirow[b]{2}{*}{ Host sample } & \multirow[b]{2}{*}{ Prevalence ${ }^{1}$} & \multicolumn{3}{|c|}{ Intensity of infection } \\
\hline & & & & Mean & Median & Range \\
\hline \multirow[t]{7}{*}{ Oswaldocruzia filiformis } & Adult males & 38 & $14(36.8)$ & 0.8 & 0 & $0-5$ \\
\hline & Adult females & 47 & $28(59.6)$ & 1.4 & 1 & $0-8$ \\
\hline & Adults & 85 & $42(49.4)$ & 1.2 & 0 & $0-8$ \\
\hline & Immature males & 38 & $9(23.7)$ & 0.5 & 0 & $0-8$ \\
\hline & Immature females & 14 & $1(7.1)$ & 0.7 & 0 & $0-10$ \\
\hline & Immatures & 52 & $10(19.2)$ & 0.5 & 0 & $0-10$ \\
\hline & Pooled & 137 & $52(37.9)$ & 0.9 & 0 & $0-10$ \\
\hline Plagiorchis molini & Pooled & 137 & $3(2.18)$ & 0.03 & 0 & $0-3$ \\
\hline
\end{tabular}

${ }^{1}$ Number of infected hosts divided by the number of hosts sampled. Values in parentheses are percentages.

A log-linear analysis was performed to distinguish simultaneously between the effects of sex and size class and the month of sampling on the presence of parasites (Table 2). The hierarchical model obtained showed that intensity was associated only with host size (immature hosts less than $45 \mathrm{~mm}$ SVL are less heavily infected than adult hosts), and not with the other factors which were arranged in pairs. A second model which forced associations between pairs of factors into one group while conserving the intensity-lizard size factor increased the significance of associations considerably (Table 2).

\section{DISCUSSION}

Although Rocha (1995) showed that the correlation between monthly prevalence of the nematode Physaloptera retusa Rudolphi, 1819 and monthly rainfall was positive in the tropidurid lizard Liolaemus lutzae Mertens in a "restinga" ecosystem from Rio de Janeiro State, Brazil, such coastal sandy habitats could be considered physiologically "dry" for helminths due to high salinity. In this instance, the rainfall determines the infection of the host. However, Zootoca vivipara inhabits very moist, freshwater habitats which remain humid throughout the year (see above), and it would therefore seem reasonable that rainfall has no influence on the infection rates. Thus, as occurs in other nematodes from reptile hosts (Bursey and Goldberg 1991), no seasonal patterns of occurrence were noted in Oswaldocruzia filiformis from $Z$. vivipara.

Infracommunities of $Z$. vivipara in the Central Pyrenees are highly depauperate. In fact, only three hosts harboured infracommunities composed of two infrapopulations (specimens of $O$. filiformis and Plagiorchis molini), whereas most lacertid lizards only harboured one infrapopulation (specimens of $O$. filiformis). Although Brillouin's index of diversity is low or very low in helminth infracommunities of saurian reptiles (Roca 1995, Roca and Hornero 1994) in comparison with other hosts such as fish (Kennedy et al. 1986) or birds (Roca et al. 1999), the value calculated for helminth infracommunities of $Z$. vivipara is the lowest known in any reptile species. This result suggests that helminth infracommunities are isolationist (Holmes and Price 1986), as in most reptiles (Aho 1990, Roca and Hornero 1994). We agree with Lewin (1992a) that the poor parasite fauna of $Z$. vivipara in comparison with other lacertid lizards is probably due to the habitat, together with small body size and different behaviour of $Z$. vivipara.

Of these, host size is the main factor determining the presence and numbers of $O$. filiformis in the intestine. The other apparent associations observed derive from variation in body size (females are larger) and season (differences of activity between adults and immature lizards or between males and females; Carretero et al. 1996, Roig et al. 1996). This seems to reflect the infrequent infection of immature specimens of $Z$. vivipara (which obviously constitute smallest individuals). Poor infection of juveniles has been recorded for other reptile species (see for example, Lewin 1922b, Roca 1996).

We interpret the greater degree of $O$. filiformis infection in female $Z$. vivipara to be an effect of the larger size of female. Sex rarely determines either the presence or the abundance of parasites (Roca 1996, Roca et al. 1990) although Lewin (1922a) noted that male $Z$. vivipara in Poland are generally more heavily infected by $O$. filiformis than females. Furthermore, in the same country, Lewin (1922b) recorded higher infection rates among male Lacerta agilis than among females. This may be due to male habit of sniffing faeces of other lizards, even touching them with the tip of the tongue whereas females do not behave in this way (Lewin 1992b). As the population of $Z$. vivipara in the Pyrenean mountains does not live with any other reptile species, and as its helminth fauna is composed of only heteroxenous parasites, we could not expect the same results as those obtained in Poland.

Zootoca vivipara is a strictly carnivorous lizard. In the Central Pyrenees it shows a generalised diet based mainly on Diptera, Araneae and Homoptera (Roig 1998). These prey are actively captured by $Z$. vivipara, making it one of the most widely foraging species 
Table 2. Results of the log-linear analysis of infection of Zootoca vivipara by Oswaldocruzia filiformis according to month (May-October), sex, size (adult/immature) and infection (+/-) of the lizards. Factors in bold are significant.

\begin{tabular}{|l|c|c|c|c|l|}
\hline \multicolumn{1}{|c|}{ Factor } & d.f. & Partial $\chi^{2}$ & $\mathrm{p}$ & Marginal $\chi^{2}$ & \multicolumn{1}{c|}{$\mathrm{p}$} \\
\hline Month & 6 & 31.28 & 0.00002 & 31.28 & 0.00002 \\
Sex & 1 & 1.37 & 0.24 & 1.37 & 0.24 \\
Size & 1 & 6.64 & 0.01 & 6.64 & 0.01 \\
Parasitisation & 1 & 6.64 & 0.01 & 6.64 & 0.01 \\
period $\times$ sex & 6 & 22.09 & 0.001 & 19.23 & 0.004 \\
month $\times$ size & 6 & 22.50 & 0.001 & 16.15 & 0.01 \\
month $\times$ parasitisation & 6 & 10.59 & 0.10 & 6.88 & 0.33 \\
sex $\times$ size & 1 & 8.72 & 0.003 & 8.38 & 0.004 \\
sex $\times$ parasitisation & 1 & 1.36 & 0.24 & 3.67 & 0.06 \\
size $\times$ parasitisation & 1 & 10.75 & 0.001 & 9.55 & 0.002 \\
month $\times$ sex $\times$ size & 6 & 8.69 & 0.19 & 10.30 & 0.11 \\
month $\times$ sex $\times$ parasitisation & 6 & 0.95 & 0.99 & 1.87 & 0.93 \\
month $\times$ size $\times$ parasitisation & 6 & 3.00 & 0.81 & 3.47 & 0.75 \\
sex $\times$ size $\times$ parasitisation & 1 & 2.08 & 0.15 & 2.37 & 0.12 \\
\hline Log-linear model (factors) & & test & value & d.f. & $p$ \\
\hline Automatic (month-sex/month-size/ & Max. likel. $\chi^{2}$ & 32.04 & 32 & 0.46 \\
$\quad$ sex-size $/$ size-parasitisation) & & Pearson $\chi^{2}$ & 36.61 & 32 & 0.26 \\
Simplified (month-sex-size/ & Max. likel. $\chi^{2}$ & 21.74 & 26 & 0.70 \\
size-parasitisation) & & Pearson $\chi^{2}$ & 19.78 & 26 & 0.80 \\
\hline
\end{tabular}

among the European lacertids (Heulin 1986). Roca (unpubl.) noted that the diet of host and its helminth diversity (species richness and abundance) are related in saurian reptiles; the more carnivorous the reptile is, the lower the helminth diversity it exhibits. Our results agree with the observations made by Roca (unpubl.) since $Z$. vivipara has a very low diversity index in association with its carnivorous feeding habits. Conversely, $Z$. vivipara contradicts previous observations made by Aho (1990) and Roca (unpubl.) who consider that sit-and-wait reptiles exhibit depauperate helminth communities, whereas widelyforaging reptiles have richer, interactive helminth communities. The extremely poor helminth infracommunities found in Z. vivipara in Spain do not match with its widely-foraging strategy (Roig et al. 1998). The low parasite recruitment may be due to the small body size of this host species, together with ecological isolation and few interactions with other reptile and amphibian species in the population studied.

Acknowledgements. M.A.C. and J.M.R. wish to thank C.R.A.M. (Centre de Recerca d'Alta Muntanya) of the Barcelona University and Conselh Generau d'Aran (local government) for the logistic support during the field work. The sampling was partially funded by a grant "Ajut a programes de recerca d'abast comarcal" of the Comissionat per a Universitats i Recerca de la Generalitat de Catalunya. Lizards were captured under the scientific hunting permits nos. $02.05 .950114 / 95$ and $04.04 .970125 / 97$ provided by the Subdirecció General de Conservació de la Natura, Departament d'Agricultura, Ramaderia i Pesca of the Generalitat de Catalunya.

\section{REFERENCES}

AHO J.M. 1990: Helminth communities of amphibians and reptiles: comparative approaches to understanding patterns and processes. In: G. Esch, A. Bush and J. Aho (Eds.), Parasite Communities: Patterns and Processes. Chapman and Hall, London, pp. 157-195.

ANONYMOUS 1999: Statistics for Windows. Statsoft Inc. Tulsa.

BIZQUERRA R. 1989: Introducción Conceptual al Análisis Multivariable. Vol. 2. PPU, Barcelona, 409 pp.

BÖHME W. 1997: Lacerta vivipara Jacquin, 1787. In: J.P. Gasc (Ed.), Atlas of Amphibians and Reptiles in Europe. Societas Europaea Herpetologica, Muséum National d'Histoire Naturelle, Paris, pp. 268-269.
BRAÑA F., BEA A. 1987: Bimodalité de la réproduction chez Lacerta vivipara (Reptilia, Lacertidae). Bull. Soc. Hérpetol. Fr. 44: 1-5.

BUSH A.O., LAFFERTY K.D., LOTZ J.M., SHOSTAK A.W. 1997: Parasitology meets ecology on its own terms: Margolis et al. revisited. J. Parasitol. 83: 575-583.

BURSEY C.R., GOLDBERG S.R. 1991: Monthly prevalences of Physaloptera retusa in naturally infected Yarrow's Spiny Lizard. J. Wildl. Dis. 27: 710-715.

CARRETERO M. A., LLORENTE G. A. 1997: Reproduction of Psammodromus algirus in coastal sandy areas of NE Spain. Amphibia-Reptilia 18: 369-383.

CARRETERO M.A., ROIG M.A., LLORENTE G.A. 1996: Ciclo reproductor femenino en una población pirenaica de Lacerta vivipara. Abstract book. Herpetologia. IV 
Congresso Luso-Espanhol, VIII Congresso Espanhol. Oporto (Portugal), p. 11-12.

GARCÍA-ADELL G., ROCA V. 1988: Helmintofauna de lacértidos de los Pirineos Centrales ibéricos. Rev. Ibér. Parasitol. 48: 257-267.

HEULIN B. 1986: Régime alimentaire estival et utilisation des ressources trophiques dans populations de Lacerta vivipara. Acta Oecol. 7 : 135-150.

HEULIN B., OSENEGG K., MICHEL D. 1994: Survie et incubation des oeufs dans deux populations ovipares de Lacerta vivipara. Amphibia-Reptilia 15: 199-219.

HOLMES J.C., PRICE P.W. 1986: Communities of parasites. In: J. Kikkawa and D.J. Anderson (Eds.), Community Ecology: Pattern and Process. Blackwell Scientific Publications, Oxford, pp. 178-213.

JOBSON J.D. 1992: Applied Multivariate Data Analysis. Volume II: Categorical and Multivariate Methods. Springer-Verlag, New York, 731 pp.

KENNEDY C.R., BUSH A.O., AHO J.M. 1986: Patterns in helminth communities: why are birds and fish different? Parasitology 93: 205-215.

LANTZ L.A. 1927: Quelques obsérvations nouvelles sur l'hérpetologie des Pyrennés Centrales. Rev. Hist. Nat. Appliq. 8: 56-61.

LEWIN J. 1992a: Parasites of Lacerta vivipara Jacquin, 1787 in Poland. Acta Parasitol. 37: 79-82.

LEWIN J. 1992b: Parasites of the sand lizard (Lacerta agilis L.) in Poland. Acta Parasitol. 37: 19-24.

MAGURRAN A.E. 1988: Ecological Diversity and its Measurement. Croom Helm, Ltd., London, 179 pp.

PANAREDA J. M., NUET J. 1973: El clima i les aigües dels Països Catalans. In: Geografia Física dels Països Catalans. Ketres, Barcelona, $226 \mathrm{pp}$.

ROCA V. 1995: An approach to the knowledge of the helminth infracommunities of Mediterranean insular lizards (Podarcis spp.). In: G.A. Llorente, A. Montori, X. Santos and M.A. Carretero (Eds.), Scientia Herpetologica. AHE, Barcelona, pp. 285-292.
ROCA V. 1996: The effect of some factors on the helminth parasite infracommunities of Podarcis lizards in the Balearic Islands (Western Mediterranean). Boll. Soc. Hist. Nat. Balears 39: 65-76.

ROCA V., FERRAGUT M.V., HORNERO M.J. 1990: Estimaciones ecológicas acerca de la helmintofauna de Lacerta schreiberi Bedriaga, 1878 (Sauria: Lacertidae) en el Sistema Central (España). Rev. Esp. Herpetol. 4: 93100.

ROCA V., HORNERO M.J. 1994: Helminth infracommunities of Podarcis pityusensis and Podarcis lilfordi (Sauria: Lacertidae) from the Balearic Islands (western Mediterranean basin). Can. J. Zool. 72: 658-664.

ROCA V., LAFUENTE M., CARBONELL E. 1999: Helminth communities in Audouin's gulls, Larus audouinii from Chafarinas Islands (western Mediterranean). J. Parasitol. 85: 13-16.

ROCHA C.F.D. 1995: Nematode parasites of the Brazilian sand lizard, Liolaemus lutzae. Amphibia-Reptilia 16: 412415.

ROIG J.M. 1998: Ecología trófica de una población pirenaica de la lagartija de turbera Zootoca vivipara (Jacquin, 1787). Graduate dissertation. Barcelona University, Barcelona, 87 pp.

ROIG J.M., CARRETERO M.A., LLORENTE G.A. 1996: Ciclo reproductor masculino en una población pirenaica de Lacerta vivipara. Abstract book. Herpetologia. IV Congresso Luso-Espanhol, VIII Congresso Espanhol. Oporto (Portugal): p. 90.

ROIG J.M., CARRETERO M.A., LLORENTE G.A. 1998: Trophic selection in a Pyrenean population of Zootoca vivipara. The Third International Symposium on the Lacertids of the Mediterranean Basin. Cres (Croacia): p. 70.

SHARPILO V.P. 1976: Parasitic Worms of the Reptilian Fauna of the USSR. Systematics, Chorology, Biology. Naukova Dumka, Moskva, 287 pp. (In Russian.) 